\author{
Electron Microscope Study of Pleistocene Diatoms* \\ NEAL R. O'BRIEN \\ Geology Department, State University of New York, Potsdam, N. Y.
}

$\underline{\text { Introduction }}$

The purpose of this paper is to report the presence of nannofossil diatoms in a Pleistocene clay in the St. Lawrence River Valley and to suggest conditions of deposition of the clay. The sample location is at water level approximately 600 feet downstream from the Snell Lock on the St. Lawrence River near Massena, New York. At this location the clay is 40 feet thick and lies directly on Ordovician dolomite. Upstream and downstream, the clay overlies two distinctive tills (U.S. Army Eng. Rept., 1958). MacClintock and Stewart (1965) have identified the lower till as the Malone till of the Cary substage and the upper till as the Fort Covington of the Valders substage. The clay containing diatoms is called the marine Champlain Sea clay by MacClintock and Stewart.

According to Fairchild (1918) as the Labradorian Glacier withdrew from New York State a fresh water lake called Lake Iroquois was formed. When the St. Lawrence Valley was freed of ice, marine waters of the Gulf of St. Lawrence invaded the St. Lawrence Valley. The marine arm of the sea is called the Gilbert Gulf by Fairchild or the Champlain Sea by others.

Evidence has been offered that the marine water of the Champlain Sea stage extended down the St. Lawrence Valley at least as far as Brockville, Ontario. Goldring (1920) studied the Pleistocene fauna found in the Champlain Sea deposits and concluded that the character of the fauna is due in large part to decreasing salinity southward in the St. Lawrence Valley. Marine foraminifara and pelecypods were sampled at the Snell Lock location (F. J. E. Wagner, personal communication). Initial study of diatoms at the same location, however, indicated abundant brackish water types suggesting normal marine conditions may not have prevailed in the Champlain Sea in the Massena, New York area. To test the hypothesis an intensive study of the fossil diatoms was undertaken using the electron microscope.

\title{
List of diatoms
}

The following diatoms were identified: Achnanthes deflexa, Achnanthes minutissima, Asterionella formosa (Hass.), Cocconeis scutellum (Ehrbg.), Cocconeis placentula (Ehrbg.) Cyclotella caspia, Cyclotella atomus, Cymbell sp., Diatoma elongatum, Diploneis smithii var. pumila (Grun.), Fragilariopsis cylindrus, Navicula grimmei, Navicula cryptocephala (Kutz), Navicula subapiculata, Navicula pusilla ( $w$. Smith), Navicula pseudoscutiformis (Hust.), Navicula sp. , Nitzschia disspata, Nitzschia palea, Nitzschia apiculata, Opephora martyi (Heribaud), Rhoicosphenia curvata, Stephanodiscus hantzschii, Synedra pulchella, Synedra tabulata (Ag.) Kutzing, Synedra sp., Thallassiosira nana, Thalassiosira chilensis, Thalassiosira sp., Thalassiothrix antarctica. Figures 1 and 2 show electron micrographs of the most abundant diatoms.

\section{Diatom Paleoecology}

Of the 17 genera and 31 different species identified, approximately half of the species are brackish water forms, one fourth are fresh water or tolerate fresh water of high mineral content, and one fourth are cold water marine forms. However, the most abundant in numbers is the latter group. Fragilariopsis cylindrus is by far the most abundant form present. Hasle (1965) states the $F$. cylindrus is a bipolar cold water species confined today to arctic and antarctic waters. Its arctic habitats include the Arctic Ocean, the Barents Sea, the North Norwegian fiords, Gulf of Finland, and the Canadian Arctic.

The Cyclotella species, which are next in abundance have been reported in brackish to marine water which include Danish fiords (Grontved, 1960), the Oslo Fiord in Norway (Braarud and Fbyd, 1958, and Braarud, Fbyd, and Hasle, 1958) and the Golfo di Napoli (Hasle, 1962). Proschkina-Lavrenko (1959) states that C. caspia has been found at salinities from $5 \%$ oo to 143. $5^{\circ} \%$ and temperatur from $15.4^{\circ} \mathrm{C}$ to $27.8^{\circ} \mathrm{C}$. Hasle (1962) reports that at the collection sites of the Cyclotella species the salinity of the Danish and Norwegian localities is $15 \%$ oo to $25 \%$ and of the Golfo di Napoli it is about 38\% . Cyclotella atomus is found in the Oslo Fiord 

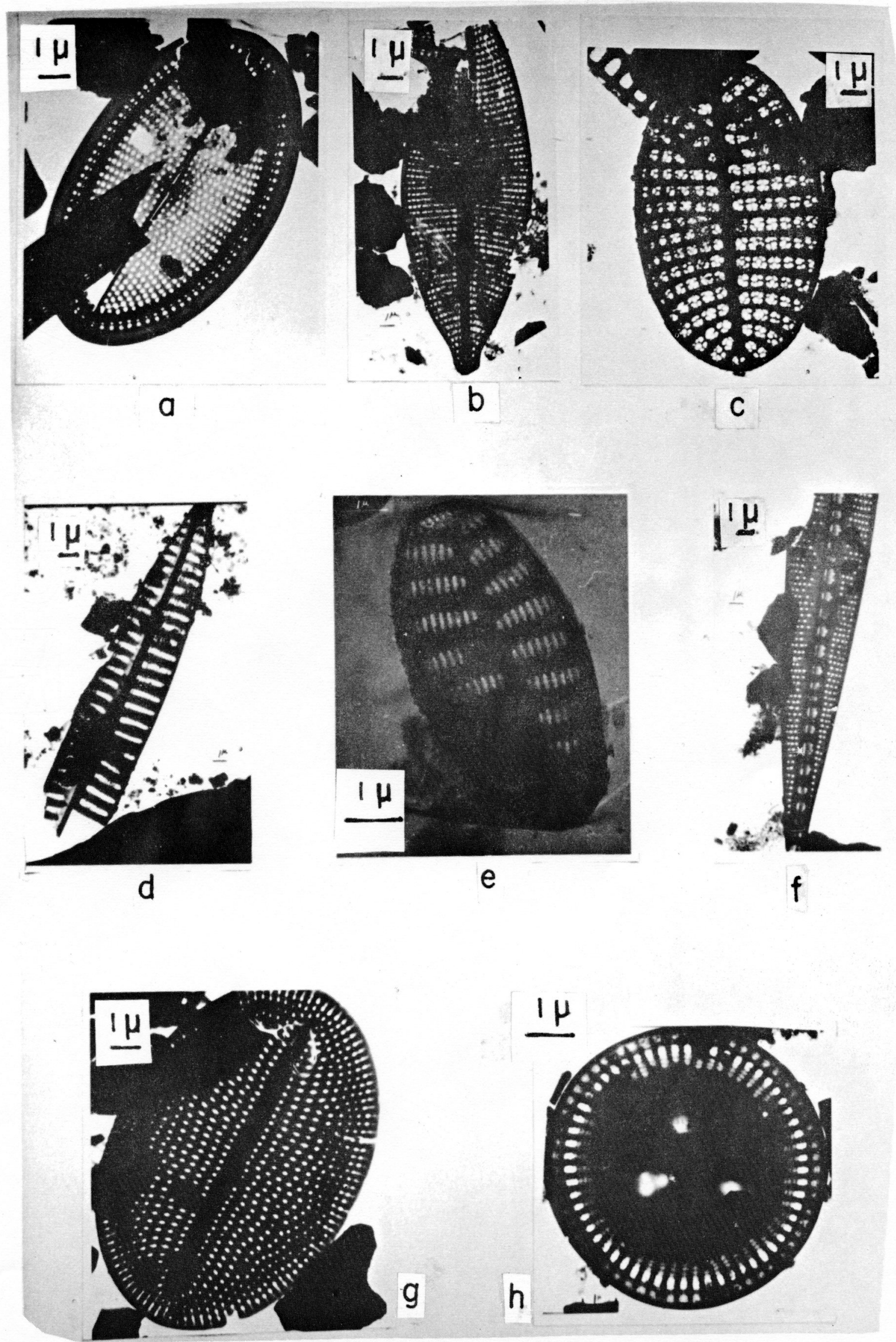

Figure 1 Electron micrographs of diatoms. a. Coconeis placentula (thrbg.); b. Navicula grammei; c. Cocconeis scutellum; d. Navicula subapiculata; e. Opephora martyi; f. Nitzschia dissipata; g. Cocconeis placentula (Ehrbg.); h. Cyclotella caspia. 


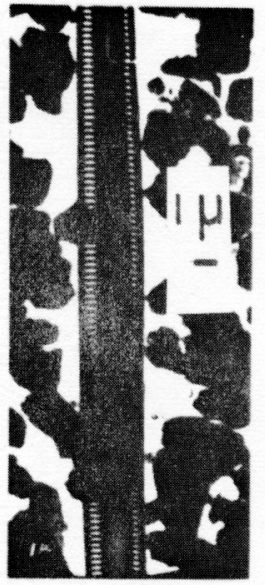

a
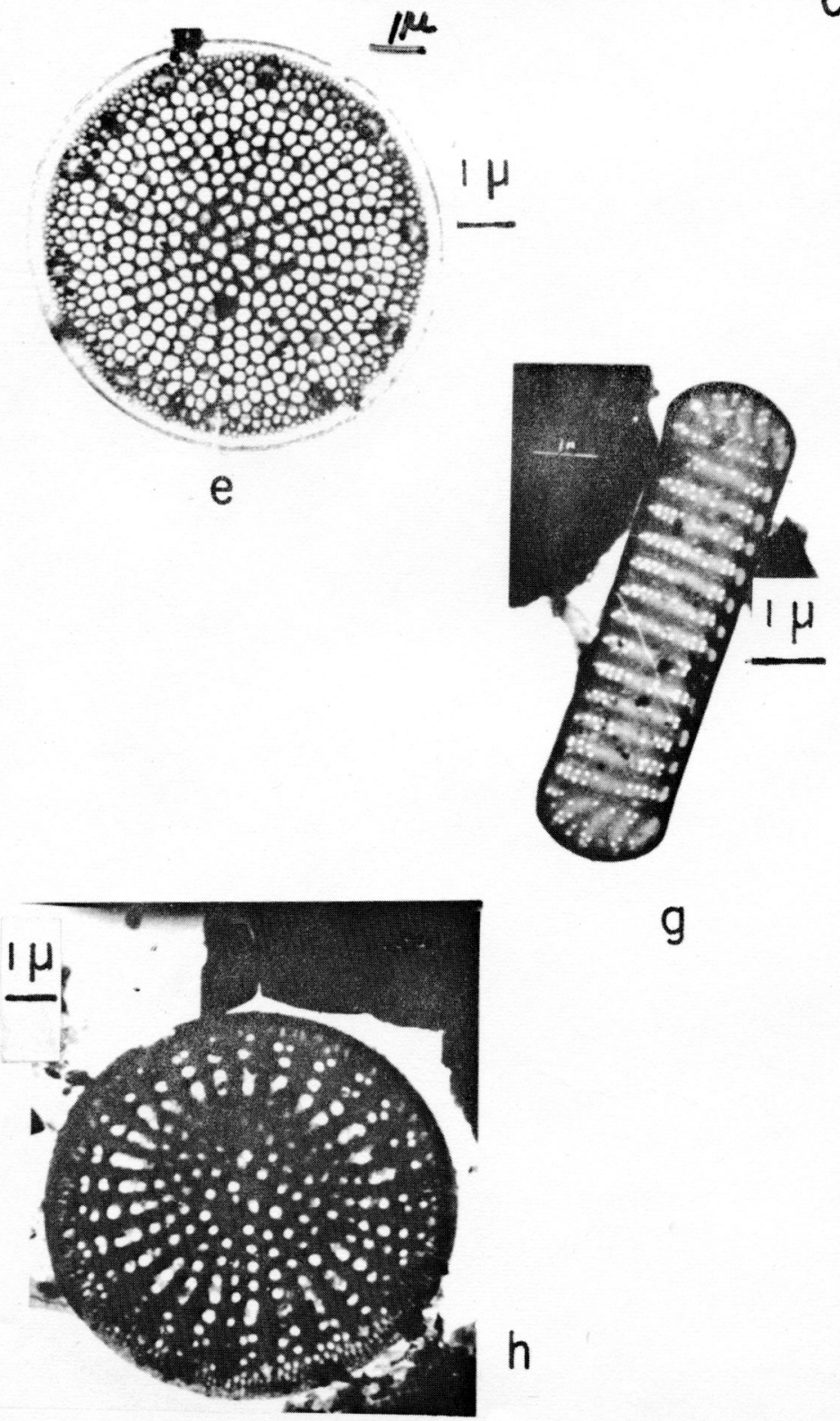

h
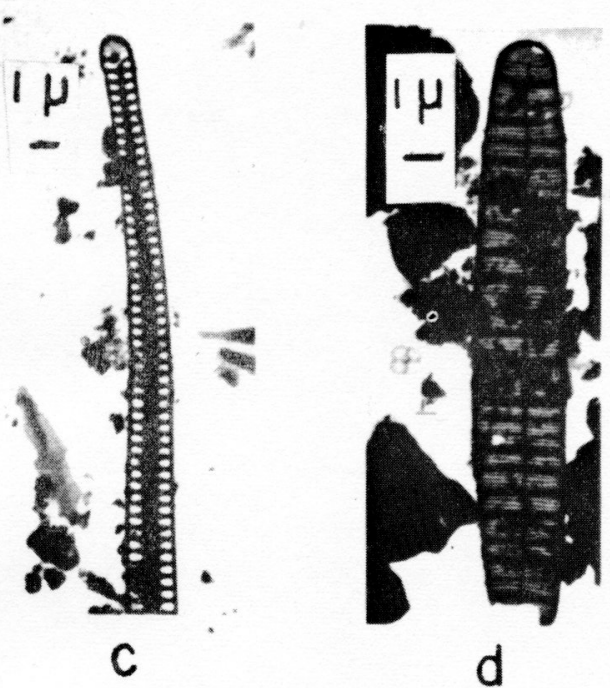

d
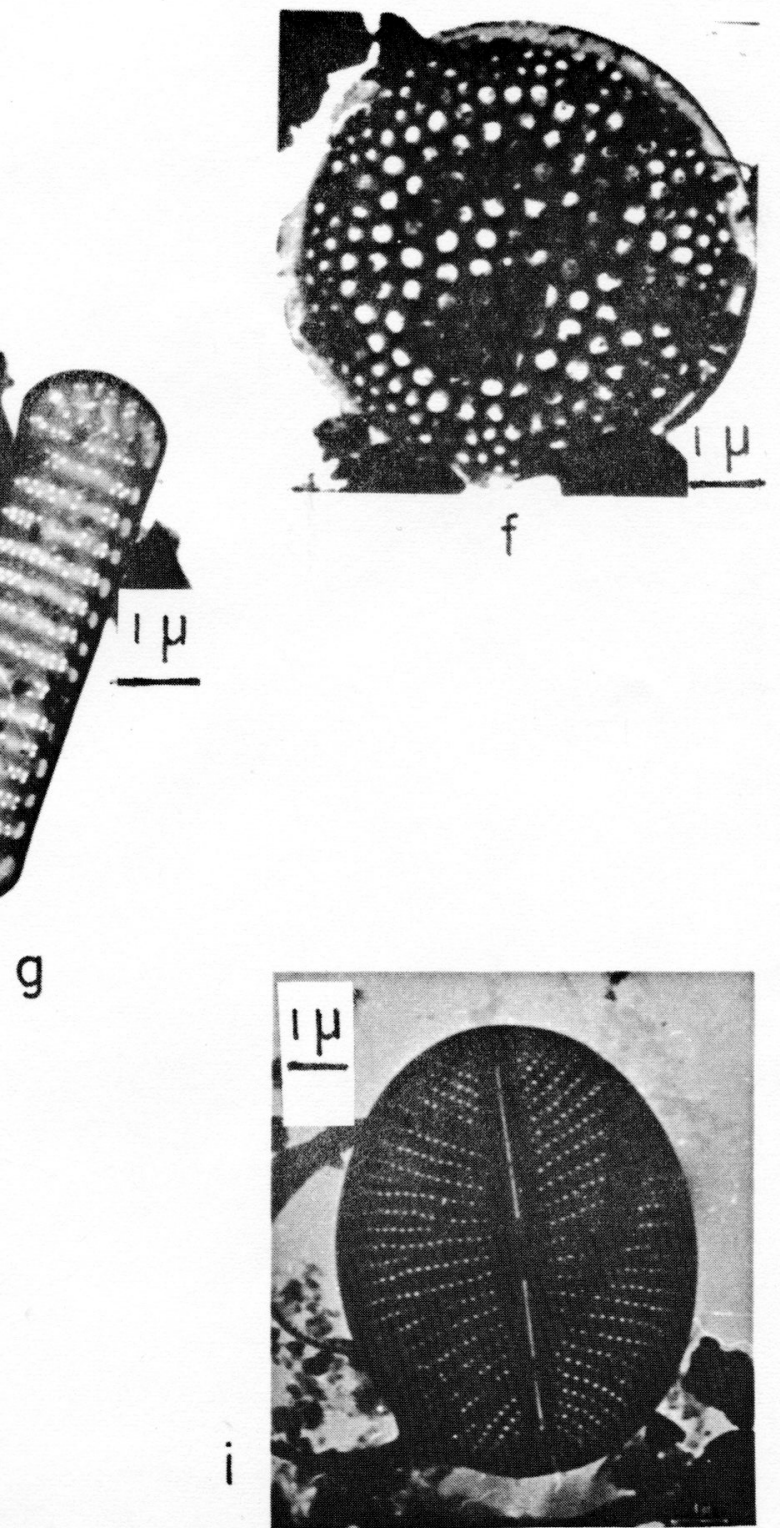

Figure 2 Electron micrographs of diatoms. a. Thalassiothrix antarctica; b. Synedra pulchella; c. Synedra tabulata; d. Diatoma elongatum; e. Thallassiosira chilensis; f. Thallassiosira nana; g. Fragilaropsis cylindrus; h. Stephanodiscus hanzschii; i. Navicula pseudoscutiformis (Hust.). 
in Norway in dominately marine water which receives varying amounts of fresh water, salinity varying from $15-20 \%$ (Hasle, 1962).

Thalassiosira species, next in abundance, suggest a marine environment (Helmcke and Krieger, 1962) while the equally abundant Stephanodiscus hantzschii, which is widely distributed in rivers today (Ryan Drum, personal communication) suggests a fresh water environment. The remaining diatoms listed above are dominantly brackish water forms. Many of the fresh water species identified, however, can tolerate water of high mineral content.

\section{Conclusion}

MacClintock and Stewart (1965, p. 81) in describing the glacial history of the region state "the conclusion, then, is again deduced that a fresh water environment followed glacial retreat, prior to the invasion by Champlain marine waters". Diatom evidence suggests two possibilities as to the salinity of the Champlain Sea in the Massena, New York area. The fresh water to brackish diatoms living in the fresh water lake described by MacClintock and Stewart may have mixed with the marine forms brought in as the tongue of the Champlain Sea invaded the valley. This implies that the salinity gradually increased until it approached that of normal marine water near Massena. Alternately, the mixed assemblage of diatoms may indicate that a constant marine salinity was never reached in the water. Possibly the sedimentary environment varied from a brackish to marine estuary which was diluted by fresh water streams, the latter being the source of the fresh water diatoms. Goldring (1920, map 2, p. 180) places the contact between the brackish and marine water of the Champlain Sea southwest of Massena, near Ogdensburg, New York. Diatom results in this study suggest that this contact should be placed as far northeast in the St. Lawrence Valley as Massena, New York. Thus it seems likely that the diatom rich clay was deposited in the brackish water of an estuary which was an extension of the Gulf of St. Lawrence.

The author is grateful to the Research Foundation of the State University of New York for financial support and to Don Fiesinger, Tom Smith, and Mark Gordon for technical assistance.

\section{References cited}

BRAARUD, T., and FOYN, B., 1958, Phytoplankton observations in a brackish water locality of southeast Norway: Nytt Mag. Bot. 6.

, and HASLE; G. R. , 1958, The marine and fresh water phytoplankton of the Dramsfiord and the adjacent part of the Oslofiord. March-December 1951: Norske Vidensk Akad. Hvalrad. Skr. 43.

FAIRCHILD, H. L., 1918, Pleistocene marine submergence of the Hudson, Champlain and St. Lawrence Valleys: New York State Museum Bulletin, No. 208-209, 76 pp.

GOLDRING, W. , 1920, The Champlain Sea: New York State Museum Bulletin, No. 239-240, p. $153-194$.

GRONTVED, J., 1960, On the productivity of microbenthos and phytoplankton in some Danish fiords: Medd. Komm. Havundersog. Kbh. N. S. 2 (17).

HASLE, G. R., 1962, Three Cyclotella species from marine localities studies in the light and electron microscopes: Nova Hedwigia, vol. 4, no, 3-4, p. 299-315.

, 1965, Nitzschia and Fragilaropsis species studied in the light and electron microscopes, III, The genus Fragilariopsis: Skrifter utgitt av Det Norske Videnskaps Akademi i Oslo I. Mat-Naturv. Klasse Ny. Series no. 21, 49 pp., 17 plates.

HELMCKE, J.G. and KRIEGER, W. , 1962, Diatomeenschalen im elektronenmikrosk-opischen Bild Part II: Berlin, J. Cramer 24 pp.

MacCLINTOCK, P. and STEWART, D. P., 1965, Pleistocene geology of the St. Lawrence Low.land: New York State Museum and Science Service, Bulletin 394, $152 \mathrm{pp}$.

PROSCHKINA-LAVRENKO, A. I. , 1959, De Cyclotella caspia Grun.: Bot. Mater. otd. 12.

U.S. ARMY CORPS OF ENGINEERS, 1958, Foundation Report - Bertrand H. Snell Lock, St. Lawrence Seaway, International Rapids Section: U.S. Army Engineer District, Buffalo, ed. Victor O. Wilson, $89 \mathrm{pp}$. 